\title{
SinTESIS CU(II)-IMPRINTED POLYMERS UNTUK EKSTRAKSI FASA PAdAT dan PRAKonsentrasi ION TEMbaga(II) DENGAN LigaN Pengkhelat 4-(2-Pyridylazo) RECORCINol
}

\author{
LingGa Rizal Harera, Tety Sudiarti, ${ }^{*}$ DAN MEYliana Wulandari.
}

Jurusan Kimia, Fakultas Sains dan Teknologi, UIN Sunan Gunung Djati Bandung, J1. A.H. Nasution No. 105 Cipadung, Bandung 40614

* email korespondensi: s_tety70@yahoo.com

ABSTRAK. Kontaminasi logam berat pada lingkungan perairan merupakan masalah besar dunia saat ini. Logam berat tidak dapat diurai atau dimusnahkan dan merupakan zat pencemar kimiawi. $\mathrm{Cu}$ (II) adalah logam berat yang bersifat racun jika masuk kedalam tubuh. Metode analisis $\mathrm{Cu}(\mathrm{II})$ sudah banyak dikembangkan salah satunya dengan teknik injeksi alir. Metode analisis ini memiliki waktu analisis yang singkat namun menggunakan pelarut yang mahal, faktor prakonsentrasi yang rendah, dan memiliki selektivitas yang rendah pula untuk ion $\mathrm{Cu}(\mathrm{II})$. Oleh karena itu, untuk meningkatkan selektivitas dilakukan pengembangan metode ekstraksi fasa padat menggunakan polimer pengkelat yaitu Ion Imprinted polymer (IIPs). Pada penelitian ini, $\mathrm{Cu}$-IP berhasil disintesis melalui polimerisasi thermal menggunakan asam salisilat dan formaldehida dengan ligan pengkelat 4-(2pyridylazo)recorcinol dengan pemanasan selama 10 jam pada temperatur $50^{\circ} \mathrm{C}$, menggunakan HCl sebagai katalis. Perbandingan stoikiometri kompleks biner $\mathrm{Cu}(\mathrm{II})$ :PAR dibuat dengan perbandingan mol 1:1 yang dihitung dengan metode job. Kapasitas adsorpsi maksimum teramati pada konsentrasi 10 ppm dengan pH 6 dan waktu kontak 80 menit. IIP digunakan untuk prakonsentrasi adsorpsi dan desorpsi dengan persen perolehan kembali sebesar 97,09 \% untuk IIP dan 53,11 \% untuk NIP. Faktor prakonsentrasi yang diperoleh pada sampel lingkungan sebesar 1,85. Dengan hasil percobaan tersebut $\mathrm{Cu}$-IP terbukti sebagai polymer fungsional dengan selektivitas dan regenerasi tinggi.

Kata Kunci : $\mathrm{Cu}(\mathrm{II})-$ Imprinted Polymers, 4-(2pyridylazo)recorcinol, ekstraksi fasa padat, prakonsentrasi.

\section{Pendahuluan}

Laju pertumbuhan penduduk dan perkembangan Ilmu Pengetahuan dan Teknologi (IPTEK) yang semakin pesat di beberapa kota besar di Indonesia menimbulkan masalah kesehatan masyarakat karena lingkungan yang tercemar. Polusi limbah rumah tangga dan perkembangan IPTEK memicu perluasan industri yang banyak menghasilkan limbah yang dibuang tanpa pengolahan yang baik.

Limbah yang dihasilkan tanpa disadari akan menimbulkan kerusakan pada lingkungan salah satunya adalah pencemaran air. Pencemaran air adalah peristiwa masuknya zat, energi, unsur, atau komponen lainnya kedalam air sehingga menyebabkan kualitas air terganggu. Indikator yang digunakan untuk mendeteksi pencemaran air adalah kandungan logam berat didalamnya. Kontaminasi logam berat pada lingkungan perairan merupakan masalah besar dunia saat ini. Logam berat tidak dapat diurai atau dimusnahkan dan merupakan zat pencemar kimiawi yang termasuk dalam kelompok Bahan Beracun dan Berbahaya (B3) serta mendapat prioritas utama dalam pencegahan dan pengendalian pencemaran air. Logam-logam ini dalam sumber air cenderung terdapat dalam kadar yang sangat rendah namun dapat terakumulasi dalam sedimen dan biota air ${ }^{[1]}$. Logam-logam berat tersebut diantaranya adalah kadmium (Cd), Kobalt (Co), Tembaga $(\mathrm{Cu})$, Raksa (Hg), dan Timbal $(\mathrm{Pb})$. Sifat beracun dan berbahaya dari logam berat ditunjukan oleh sifat fisik dan kimia bahan baik dari segi kuantitas maupun kuantitasnya. pencemaran lingkungan antara lain disebabkan oleh limbah yang dihasilkan oleh industriindustri maupun produk yang dihasilkannya. 
Salah satu pencemaran yang berbahaya adalah pencemaran logam Tembaga $(\mathrm{Cu})^{[2]}$.

Tembaga $(\mathrm{Cu})$ adalah sebuah nutrisi yang penting untuk seluruh tumbuhan dan hewan. Pada hewan termasuk manusia banyak ditemukan ion tembaga dalam aliran darah, sebagai kofaktor pada berbagai macam enzim. Logam Berat $\mathrm{Cu}$ walaupun bersifat esensial bagi seluruh makhluk hidup namun akan menjadi racun jika terakumulasi dalam jumlah besar di dalam tubuh. Tembaga mempunyai bilangan oksidasi +1 dan +2 , akan tetapi yang jumlahnya melimpah adalah adalah $\mathrm{Cu}$ dengan bilangan oksidasi +2 atau $\mathrm{Cu}(\mathrm{II})$, karena $\mathrm{Cu}(\mathrm{I})$ di air mengalami disproporsionasi membentuk sebagai senyawa yang tidak larut ${ }^{[3]}$. Dengan demikian $\mathrm{Cu}$ yang stabil adalah $\mathrm{Cu}(\mathrm{II}) . \mathrm{Cu}$ (II) dalam jumlah kecil diperlukan oleh tubuh untuk pembentukan sel-sel darah merah, tetapi dalam jumlah besar dapat rnenyebabkan rasa yang tidak enak pada lidah. Kadar $\mathrm{Cu}$ maksimum yang diperbolehkan adalah 0,05-1.5 $\mathrm{ppm}^{[4]}$. Oleh karena itu, perlu dikembangkan suatu metode penentuan kadar tembaga di perairan dalam jumlah renik.

Metode umum untuk analisis $\mathrm{Cu}(\mathrm{II})$ adalah metode spektrofotometri serapan atom $^{[5]}$. Selain itu dikembangkan Metode ekstraksi fasa padat (solid phase extraction) untuk meretensi logam menggunakan adsorben padat. Teknik Solid Phase Extraction (SPE) juga dikenal sebagai ekstraksi padat-cair adalah teknik pemisahan yang digunakan untuk menghapus analit dari campuran. Pelarut pada metode ini menggunakan pelarut polar-polar, agak polar atau non polar atau penyangga dari unsur senyawa yang sesuai dengan sampel yang berfungsi untuk menyeimbangkan cartridge. Metode ini memiliki prakonsentrasi yang tinggi, waktu analisis singkat dan nilai perolehan kembali yang tinggi ${ }^{[6]}$. Metode lain yaitu teknik injeksi alir (flow injection analysis) juga dikembangkan untuk analisis kadar $\mathrm{Cu}$ (II). Metode ini memiliki waktu analisis yang singkat namun menggunakan pelarut yang mahal dan faktor prakonsentrasi yang rendah.
Untuk mengatasi kelemahan metode diatas kemudian mulai dikembangkan metode Ion Imprinted polymers (IIPs) dengan polimerisasi asam salisilat dan formaldehida yang dinilai memiliki selektivitas yang lebih tinggi dari metode sebelumnya.

Metode Ion Imprinted polymers (IIPs) memiliki kelebihan yaitu adanya selektivitas yang tinggi dan preparasinya mudah. Metode pencetak ion menghasilkan cetakan ion logam yang terikat dalam polimer, selanjutnya dilepas dari matriks polimer menghasilkan cetakan yang selektif terhadap ion yang dicetak ${ }^{[7]}$. IIPs telah diaplikasikan dalam berbagai macam analisis seperti prakonsentrasi, pemisahan dan pemurnian karena selektivitasnya yang tinggi. Hal itu disebabkan karena adanya Memory effect dari suatu polimer terhadap interaksi ion logam dengan ligan spesifik, geometri koordinasi, bilangan koordinasi, muatan dan juga ukuran ion logam ${ }^{[8]}$.

$\mathrm{Cu}$-Imprinted polymer (Cu-IIPs) disiapkan dengan mengekstraksi logam $\mathrm{Cu}$ dari larutan kompleks binernya menggunakan 4-(2Pyridylazo) Recorcinol (PAR) yang memiliki selektifitas yang tinggi untuk mengekstraksi $\mathrm{Cu}(\mathrm{II})$ dari larutannya. Monomer yang digunakan adalah asam salisilat yang mampu menghasilkan polimer tahan panas dan formaldehid sebagai pengikat silangnya, koordinasinya kuat dan stabilitasnya baik untuk ion $\mathrm{Fe}^{3+}, \mathrm{Cu}^{2+}, \mathrm{Ni}^{2+}, \mathrm{Co}^{2+}, \mathrm{Zn}^{2+}, \mathrm{Cd}^{2+}$ dan $\mathrm{Pb}^{2+}$ [9]. Asam salisilat berupa kristal tidak berwarna, bersifat stabil, mudah terbakar, pereduksi dan pengoksidasi kuat, sedikit larut dalam air, sebaliknya mudah larut dalam pelarut organik polar seperti etanol ${ }^{[10]}$. Formaldehid dipilih karena senyawa ini merupakan pengikat silang yang baik yang digunakan dalam sintesis kopolimer seperti fenol-formaldehida dan asam salisilat-formaldehida.

Beberapa parameter yang mungkin dapat mempengaruhi keberhasilan analisis dan prakonsentrasi $\mathrm{Cu}(\mathrm{II})$ dalam penelitian ini seperti pengaruh $\mathrm{pH}$, waktu kontak, kapasitas adsorbsi, adsorpsi dan desorpsi dan pengaruh 
matriks sampel akan diidentifikasi melalui prosedur ekstraksi fasa padat menggunakan asam salisilat dan formaldehida sebagai polimer dan ligan 4-(2- Pyridylazo) Recorcinol (PAR) sebagai pengkhelat.

\section{Teori}

Ion impirinted polymers atau polimer pencetak ion bertujuan untuk mendapatkan absorben yang selektif terhadap ion logam yang diinginkan. Selektivitas yang tinggi dari polimer-polimer pencetak ion (IIPs) disebabkan adanya efek memori dari suatu polimer terhadap interaksi ion logam dengan ligan spesifik, geometri koordinasi, bilangan koordinasi ion logam, muatan dan juga ukuran ion logam tersebut ${ }^{\text {17\}. Penyusunan IIPs }}$ melibatkan kompleksasi ion sasaran (template) dengan monomer fungsional atau dikenal dengan ligan atau substrat dan diikuti polimerisasi dengan pengikat silang yang dapat mengikat monomer fungsional dengan kompleks biner ion yang akan dicetak. Setelah terjadi polimerisasi, dilakukan pencucian dengan pelarut yang cocok untuk melepaskan ion logam dari polimer. ketika ion logam keluar dari polimer, efek memori yang ada pada Imprinted polymers terbentuk, akan selektif terhadap bentuk, ukuran dan fungsi ion yang masuk kedalamnya ${ }^{[11]}$.

Metode Ion-Imprinted Poliymers (IIPs) bertujuan untuk mendapatkan adsorben yang selektif terhadap ion logam yang diinginkan. Teknik ini dapat meningkatkan selektivitas karena ion logam berperan sebagai cetakan yang terbentuk dari polimer yang akan mencetak ion logam tersebut. Metode IIPs menghasilkan cetakan ion logam yang selektif terhadap ion yang dicetak. Selain itu metode pencetakan ini penyiapannya mudah, relatif murah, dan senyawanya stabil pada suhu kamar untuk waktu yang cukup lama. Metode polimer pencetak ion sangat meyakinkan dalam prakonsentrasi ekstraksi fasa-padat karena dapat digunakan pada konsentrasi analit yang rendah atau untuk pemisahan ion yang berikatan pada matriks kompleks ${ }^{[12]}$

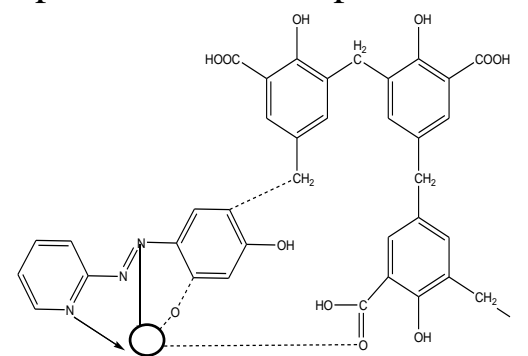

Gambar 1 Struktur molekul Cu-IP

\section{Alat dan Bahan}

Peralatan yang digunakan adalah peralatan gelas standar laboratorium kimia, digunakan pula beberapa peralatan lainnya yaitu: anak stirrer, hot plate, alat refluks, thermometer, dan $\mathrm{pH}$ meter. Analisis pada tahapan sintesis menggunakan spektrometri infra red transformasi Fourier (FTIR). Penentuan analisis kadar ion logam $\mathrm{Cu}^{2+}$ dilakukan dengan spektrofotometer serapan atom (SSA). Bahan-bahan yang digunakan dalam penelitian ini memiliki derajat kemurnian pro analisis (p.a). adapun bahanbahan yang di gunakan adalah 4-(2pyridylazo)resorcinol (PAR), asam salisilat, formaldehida $37 \%$, EDTA, $\mathrm{HCl}, \mathrm{Cu}(\mathrm{II})$ asetat, aqua $\mathrm{dm}$ dan larutan buffer untuk $\mathrm{pH}$ 4-7 digunakan $\mathrm{CH}_{3} \mathrm{COOH} / \mathrm{CH}_{3} \mathrm{COONa}$.

\section{Metode Penelitian}

Pada penelitian ini mula-mula disintesis $\mathrm{Cu}$ (II)- imprinted polymers (Cu-IP) melalui polimerisasi termal asam salisilat dan formaldehida dengan adanya logam $\mathrm{Cu}(\mathrm{II})$ 4(2-pyridylazo)resorcinol (PAR) dengan pemanasan selama 10 jam pada temperatur 50 $\pm 1{ }^{0} \mathrm{C}$ dan $\mathrm{HCl} 2 \mathrm{M}$ sebagai katalis. Untuk melepas ion $\mathrm{Cu}(\mathrm{II})$ partikel polimer ini direaksikan dengan larutan EDTA. Untuk sintesis NIP dilakukan langkah yang sama dengan IIP hanya saja tidak melibatkan $\mathrm{Cu}$ Asetat. Hasil sintesis IIP sebelum dan setelah didesorpsi oleh EDTA dan NIP kemudian dikarakterisasi menggunakan FTIR untuk mengetahui gugus fungsi yang terbentuk di dalamnya. 
Cu(II)_Imprinted Polymer hasil sintesis, dianalisis kemampuannya untuk dapat meretensi ion Logam $\mathrm{Cu}(\mathrm{II})$. Analisis ini menggunakan metode Batch. IIP dan NIP dikontakkan dengan larutan $\mathrm{Cu}(\mathrm{II})$ kemudian ditentukan $\mathrm{pH}$ optimum, waktu kontak optimum, kapasitas adsorpsi. Instrumen yang digunakan untuk analisis ini adalah dengan spektrofotometer AAS dengan panjang gelombang 324,73 nm untuk serapan $\mathrm{Cu}(\mathrm{II})$. Hasil analisis ini kemudian akan digunakan dalam penelitian selanjutnya. Penentuan $\mathrm{pH}$ optimum dengan metode batch dilakukan dengan cara melarutkan 0,1 gram IIP dengan larutan $\mathrm{Cu}(\mathrm{II})$ standar $1 \mathrm{ppm}$ selama 2 jam dengan variasi $\mathrm{pH} 4,5,6$, dan 7 . Hasilnya kemudian diukur absorbansinya lalu dihitung kapasitas absorpsi pada variasi $\mathrm{pH}$ yang berbeda.

\section{Hasil dan Diskusi}

Sintesis Ion Imprinted polymers diawali dengan pembentukan kompleks biner antara logam dan ligan pengkelat. Pada penelitian ini ion $\mathrm{Cu}$ (II) yang digunakan berasal dari senyawa $\mathrm{Cu}$ (II)asetat yang merupakan padatan berwarna hijau tua. Sedangkan untuk ligan pengkelat digunakan senyawa 4-(2-pyridylazo)recorcinol (PAR) yang merupakan senyawa berwarna oranye. Hasil sintesis berupa kompleks biner $\mathrm{Cu}(\mathrm{II})-\mathrm{PAR}$.

Pembentukan kompleks biner $\mathrm{Cu}(\mathrm{II})$ PAR dilakukan menggunakan metode job untuk meramalkan stoikiometri sistem yang menyatakan perbandingan pereaksi dalam senyawa. Dengan metode ini dapat diamati interaksi antara ion logam dengan ligan. Pereaksi disini adalah ion logam $\mathrm{Cu}$ (II) dan ligan pengkelat 4-(2-pyridylazo)recorcinol $(P A R)$. Untuk mendapatkan absorbansi maksimum dari pembentukan kompleks biner tersebut. Perbandingan mol untuk logam $\mathrm{Cu}$ (II) dibuat tetap sedangkan mol ligan PAR di variasikan yaitu dengan perbandingan $\mathrm{Cu}$ : PAR ; $1: 0,1 ; 1: 0,5 ; 1: 1 ; 1 ; 1,5 ; 1: 2$. Data yang di peroleh ditampilkan pada grafik Gambar 2.
Dari perpotongan grafik tersebut, diperoleh dua persamaan garis, yaitu (1) $\quad \mathrm{Y}=$ $0,453 \mathrm{x}+0,028$, dan (2) $\mathrm{Y}=0,407 \mathrm{x}+0,054$. Dari kedua persamaan garis ini nilai $\mathrm{x}$ dihitung, dan nilai $\mathrm{x}$ hasil perhitungan adalah 0,56. Angka 0,56 menujukkan fraksi mol yang ditunjukkan oleh perbandingan mol 1:1, dimana merupakan perbandingan maksimum untuk kompleks $\mathrm{Cu}$ (II)-PAR yang masih berada dalam garis linearitas. Peningkatan absorbansi yang lebih dari angka 0,8 akan menyebabkan kurva menjadi tidak linier. Senyawa kompleks biner $\mathrm{Cu}$ (II)-PAR kemudian dibuat dari $\mathrm{Cu}(\mathrm{II})$ asetat dengan ligan 4-(2pyridylazo)resorcinol dengan perbandingan 1:1. Senyawa kompleks yang terbentuk dapat diamati secara visual yaitu adanya perubahan warna larutan menjadi coklat pekat. Mekanisme reaksi secara umum digambarkan pada Gambar 3.

Kompleks biner $\mathrm{Cu}(\mathrm{II})-\mathrm{PAR}$ yang telah dihasilkan dicampurkan ke dalam alat refluks yang telah berisi asam salisilat dan formaldehida, dengan perbandingan mol asam salisilat : formaldehida $(0,1 \mathrm{~mol}: 0,3 \mathrm{~mol})$,

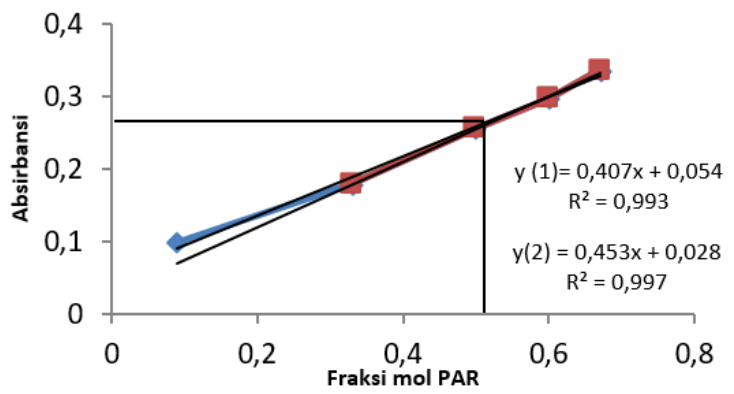

Gambar 2 Kurva Metode Job Kompleks $\mathrm{Cu}(\mathrm{II})-\mathrm{PAR}$

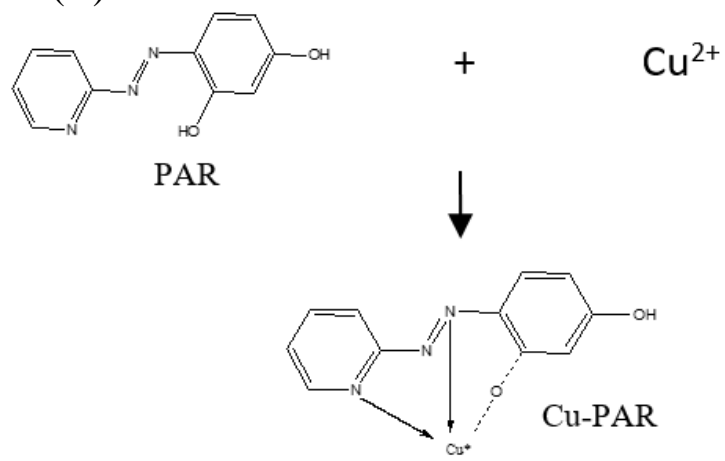

Gambar 3 Mekanisme reaksi kompleks biner $\mathrm{Cu}(\mathrm{II})$-PAR 
dengan $\mathrm{HCl} 2 \mathrm{M}$ sebagai katalis. Monomer yang digunakan adalah asam salisilat karena asam salisilat mampu menghasilkan polimer tahan panas dan formaldehid dipilih sebagai pengikat silangnya, karena formaldehid merupakan pengikat silang yang baik yang digunakan dalam sintesis kopolimer seperti fenolformaldehida dan asam salisilat-formaldehida koordinasinya kuat dan stabilitasnya baik untuk ion $\mathrm{Fe}^{3+}, \mathrm{Cu}^{2+} \mathrm{Ni}^{2+}, \mathrm{Co}^{2+} \mathrm{Zn}^{2+}, \mathrm{Cd}^{2+}$ dan $\mathrm{Pb}^{2+}$.

Selama proses refluks dengan pengadukan yang kontinyu menimbulkan bau yang menyengat yang diakibatkan oleh penggunaan formaldehida sebagai pengikat silang. Proses refluks ini dilakukan selama 8 jam agar terjadi polimerisasi dengan sempurna. Senyawa yang diperoleh setelah direfluks berupa padatan hitam yang sangat lengket dan berbau menyengat. Strukturnya secara fisik sangat kaku berbentuk gumpalan. Hal itu disebabkan karena penggunaan formaldehida sebagai agen pengikat silang yang membentuk penghubung dalam polimer sehingga terbentuk polimer yang rigid. Secara umum, mekanisme pembentukan $\mathrm{Cu}$-IP digambarkan dalam

\section{Gambar 4.}

Dalam mekanisme reaksi pembentukan $\mathrm{Cu}$-IP dapat dilihat pada Gambar 4 bahwa telah terentuk ikatan kovalen koordinasi antara polimer dan logam. Ikatan tersebut terbentuk karena terdapat pasangan elektron bebas dari $\mathrm{O}$ dan $\mathrm{N}$ yang berikatan kuat dengan lon $\mathrm{Cu}$ (II). $\mathrm{Cu}$ telah terikat sempurna dan tercetak dalam polimer. PAR bertindak sebagai ligan tridentat yang mengikat ion $\mathrm{Cu}$ (II) dan asam salisilat. Senyawa tersebut masih mengandung ion $\mathrm{Cu}(\mathrm{II})$. Untuk membentuk cetakan ion yang memikiki efek ingatan mengenai orbital

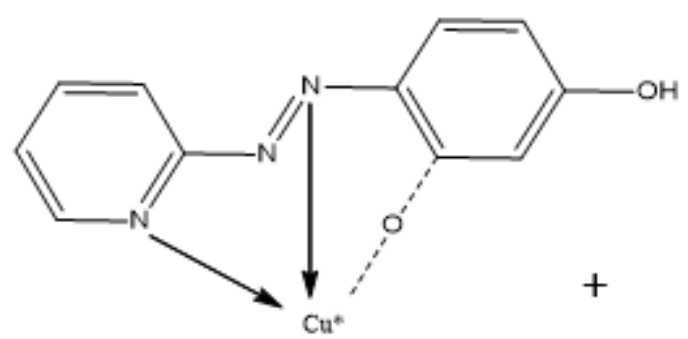

PAR
Asam salililat

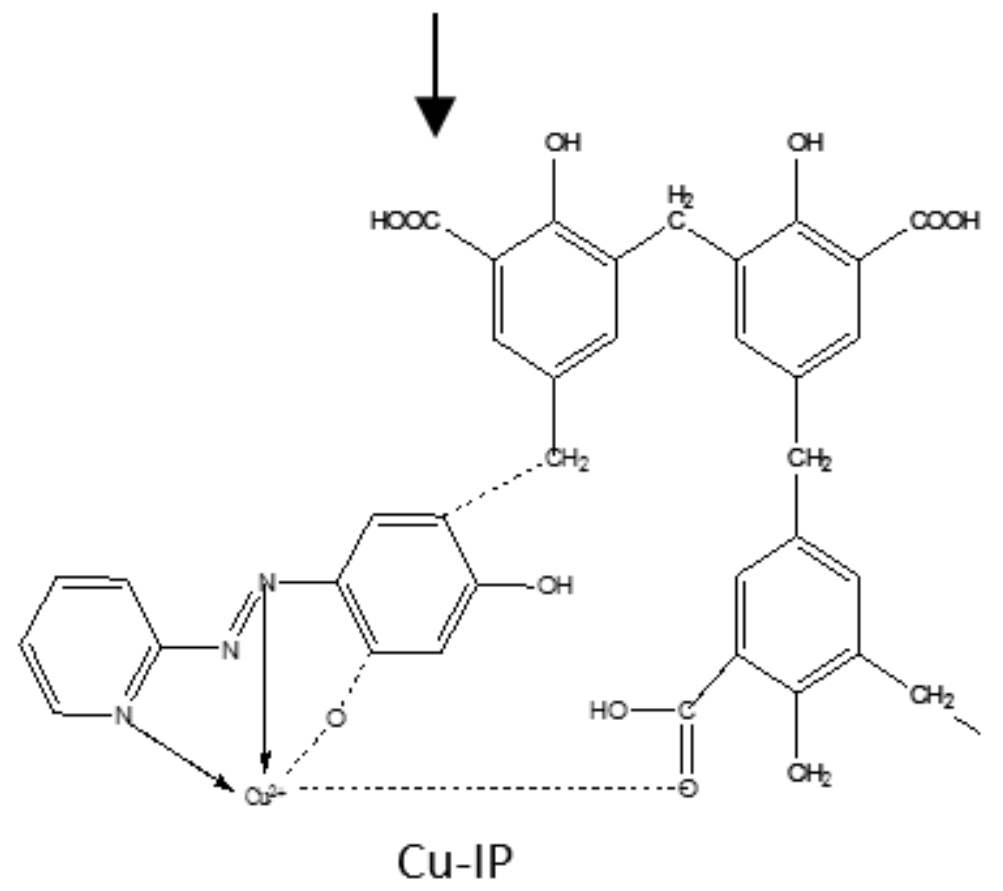

Gambar 4 Mekanisme reaksi pembentukan $\mathrm{Cu}-\mathrm{IP}$ 
molekul, ukuran partikel serta bilangan geometri molekul, maka $\mathrm{Cu}$-IP yang telah dibentuk harus di-leching dengan EDTA 0,05 $\mathrm{M}$ untuk melepaskan ion $\mathrm{Cu}$ (II)yang terkandung pada Ion Imprinted polymer tersebut. EDTA merupakan sebuah ligan yang berfungsi untuk mendesorpsi dan dapat membentuk senyawa kompleks dengan ion logam dengan kuat. EDTA dapat membentuk senyawa kompleks yang mantap dengan sejumlah besar ion logam. EDTA berperan sebagai agen pengkelat yang memiliki ligan heksadentat sehingga mampu mengikat dan meretensi $\mathrm{Cu}$ (II) dengan kuat.

Selain itu juga disintesis senyawa NIP sebagai pembanding. Prosedur sintesis Non Imprinted polymer ini sama dengan pembuatan Ion Imprinted polymer, hanya saja tidak melibatkan $\mathrm{Cu}(\mathrm{II})$ asetat. 1 mol PAR direkasikan dengan 0,1 mol asam salisilat dan 0,3 mol formaldehid kemudian direfluks selama 8 jam dengan katalis $\mathrm{HCl}$. Senyawa NIP ini tidak mengandung ion $\mathrm{Cu}(\mathrm{II})$ sehingga NIP ini tidak mempunyai ingatan ataupun "memory effect" terhadap suatu logam tertentu, berbeda dengan IIP yang hanya dapat mengikat satu logam saja karena mempunyai ingatan terhadap ion yang telah terikat terlebih dahulu.

Hasil sintesis IIP sebelum dan setelah didesorpsi oleh EDTA dan NIP kemudian dikarakterisasi menggunakan FTIR untuk mengetahui gugus fungsi yañg terbentuk di dalamnya. Gugus fungsi yang terbentuk sangat penting untuk diketahui agar dapat membuktikan bahwa $\mathrm{Cu}$-IP dan NIP yang diinginkan telah terbentuk. Hasil analisis menggunakan FTIR digambarkan pada Gambar 5 yang penjelasan vibrasinya dapat disajikan pada Tabel 1.
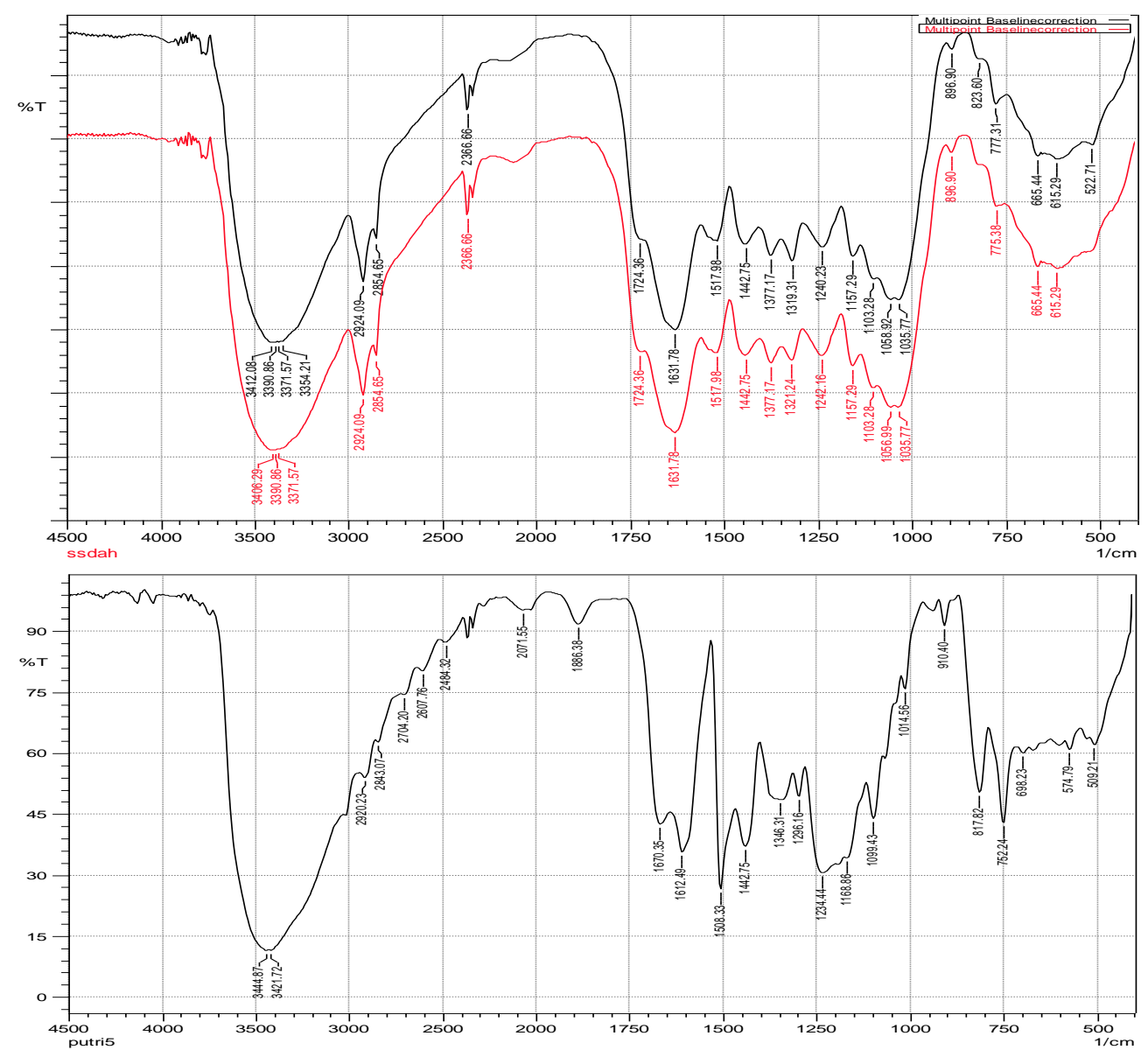

Gambar 5 (a) hasil karakterisasi Cu-IP sebelum didesorpsi oleh EDTA; (b) hasil karakterisasi IIP setelah diadsorpsi oleh EDTA; (c) hasil kakrakterisasi NIP 
Tabel 1 Hasil spektrum IR untuk Cu-IP, IIP dan NIP

\begin{tabular}{|c|c|c|c|}
\hline \multirow[b]{2}{*}{ No } & \multicolumn{3}{|c|}{ Gugus Fungsi yang teramati } \\
\hline & Spektrum Cu-IP & $\begin{array}{l}\text { Spektrum IIP setelah } \\
\text { desorpsi oleh EDTA }\end{array}$ & Spektrum NIP \\
\hline 1 & $\begin{array}{l}\text { Puncak serapan utama } \\
\text { untuk Vibrasi O-H pada } \\
\text { panjang gelombang } 3330- \\
3462 \mathrm{~cm}^{-1} \text { adalah gugus } \\
\text { karboksilat }\end{array}$ & $\begin{array}{l}\text { Puncak serapan }-\mathrm{OH} \text { dari } \\
\text { gugus karboksilat berubah } \\
\text { menuju bilangan yang lebih } \\
\text { kecil menjadi } 3406,29 \mathrm{~cm}^{-1}\end{array}$ & $\begin{array}{l}\text { Puncak serapan }-\mathrm{OH} \\
\text { berada pada } 2920,23 \mathrm{~cm}^{-1} \\
\text { hingga } 3444,87 \mathrm{~cm}^{-1} \\
\text { adalah vibrasi ulur dari } \\
\text { monomer asam salisilat }\end{array}$ \\
\hline 2 & $\begin{array}{l}\text { Puncak serapan } \mathrm{C}=\mathrm{O} \\
\text { teramati pada bilangan } \\
\text { gelombang } 1631,78 \mathrm{~cm}^{-1}\end{array}$ & $\begin{array}{l}\text { Puncak serapan } \mathrm{C}=\mathrm{O} \\
\text { teramati pada bilangan } \\
\text { gelombang } 1631,78 \mathrm{~cm}^{-1}\end{array}$ & $\begin{array}{l}\text { Puncak serapan } \mathrm{C}=\mathrm{O} \\
\text { begeser ke bilangan } \\
\text { gelombang } 1508,33 \mathrm{~cm}^{-1}\end{array}$ \\
\hline 3 & $\begin{array}{l}\text { Puncak serapan cincin } \\
\text { aromatis } \\
\text { teramati pada bilangan } \\
\text { gelombang } 777,31 \mathrm{~cm}^{-1}\end{array}$ & $\begin{array}{lrr}\text { Puncak } & \text { serapan cincin } \\
\text { aromatis } & \text { tersubtitusi } \\
\text { berubah } & \text { ke } & \text { panjang } \\
\text { gelombang } & 775,38 \mathrm{~cm}^{-1}\end{array}$ & $\begin{array}{l}\text { Cincin aromatik yang } \\
\text { tersubtitusi lebih banyak } \\
\text { pada panjang gelombang } \\
752,24 \mathrm{~cm}^{-1}\end{array}$ \\
\hline 4 & $\begin{array}{l}\text { Puncak serapan } \mathrm{C}=\mathrm{N} \text { dan } \\
\mathrm{N}=\mathrm{N} \text { pada panjang } \\
\text { gelombang } 1250-2000 \mathrm{~cm}^{-}\end{array}$ & $\begin{array}{l}\text { Puncak serapan } \mathrm{C}=\mathrm{N} \text { dan } \\
\mathrm{N}=\mathrm{N} \text { pada panjang } \\
\text { gelombang } 1250-2000 \mathrm{~cm}^{-} \\
1\end{array}$ & $\begin{array}{l}\text { Puncak serapan } \\
\text { ulur } \quad \mathrm{C}=\mathrm{N} \quad \text { aromatik } \\
\text { teramati pada panjang } \\
\text { gelombang } 1234,44 \mathrm{~cm}^{-1}\end{array}$ \\
\hline 5 & $\begin{array}{l}\text { Vibrasi Streching C-N } \\
\text { teramati pada panjang } \\
\text { gelombang } 1058,92 \mathrm{~cm}^{-1}\end{array}$ & $\begin{array}{l}\text { Vibrasi Streching C-N } \\
\text { berubah ke panjang } \\
\text { gelombang } 1056,99 \mathrm{~cm}^{-1}\end{array}$ & \\
\hline
\end{tabular}

Cu(II)_Imprinted Polymer hasil sintesis, dianalisis kemampuannya untuk dapat meretensi ion Logam $\mathrm{Cu}(\mathrm{II})$. Analisis ini menggunakan metode Batch. IIP dan NIP dikontakkan dengan larutan $\mathrm{Cu}(\mathrm{II})$ kemudian ditentukan $\mathrm{pH}$ optimum, waktu kontak optimum, kapasitas adsorpsi. Instrumen yang digunakan untuk analisis ini adalah dengan spektrofotometer AAS dengan panjang gelombang 324,73 nm untuk serapan $\mathrm{Cu}(\mathrm{II})$. Hasil analisis ini kemudian akan digunakan dalam penelitian selanjutnya.

Penentuan $\mathrm{pH}$ optimum dengan metode batch dilakukan dengan cara melarutkan 0,1 gram IIP dengan larutan $\mathrm{Cu}(\mathrm{II})$ standar $1 \mathrm{ppm}$ selama 2 jam dengan variasi $\mathrm{pH} 4,5,6$, dan 7 . Hasilnya kemudian diukur absorbansinya lalu dihitung kapasitas absorpsi pada variasi $\mathrm{pH}$ yang berbeda.

Kapasitas adsorpsi $\mathrm{Cu}(\mathrm{II})$ meningkat seiring dengan makin meningkatnya $\mathrm{pH}$ larutan. Setelah mencapai $\mathrm{pH}$ optimum kemudian terjadi penurunan pada kapasitas adsorpsi (Gambar 6). Hal itu disebabkan karena dalam larutan, konsentrasi ion $\mathrm{H}_{3} \mathrm{O}^{+}$ besar sehingga kemungkinan terjadi kompetisi dengan ion $\mathrm{Cu}(\mathrm{II})$ saat polimerisasi terjadi. Namun, seiring meningkatnya $\mathrm{pH}$, adsorpsi ion $\mathrm{Cu}$ (II) akan lebih besar dibandingkan dengan adsorpsi ion $\mathrm{H}_{3} \mathrm{O}^{+}$sehingga kapasitas adsorpsi $\mathrm{Cu}(\mathrm{II})$ akan meningkat.

Ketika $\mathrm{pH}$ larutan berada di atas $\mathrm{pH} 6$, nilai retensi akan menurun karena pada $\mathrm{pH}$ diatas 6 akan terjadi penjenuhan dan pembentukan hidroksida $\mathrm{Cu}(\mathrm{OH})_{2}$. Hal itu menyebabkan jumlah $\mathrm{Cu}$ yang ada dalam larutan akan berkurang karena larutan basa akan merubah $\mathrm{Cu}(\mathrm{II})$ menjadi $\mathrm{Cu}(\mathrm{OH})_{2}$. Pada penelitian ini, $\mathrm{pH}$ optimum yang digunakan untuk adsorpsi adalah pada $\mathrm{pH} 6$.

Selanjutnya ditentukan Waktu kontak optimum untuk dapat mengetahui berapa lama waktu kontak yang baik agar polimer mampu mengadsorpsi $\mathrm{Cu}(\mathrm{II})$ secara maksimal. Untuk menentukan waktu kontak optimum, 0,1 gram IIP dan NIP dikontakkan dengan larutan 


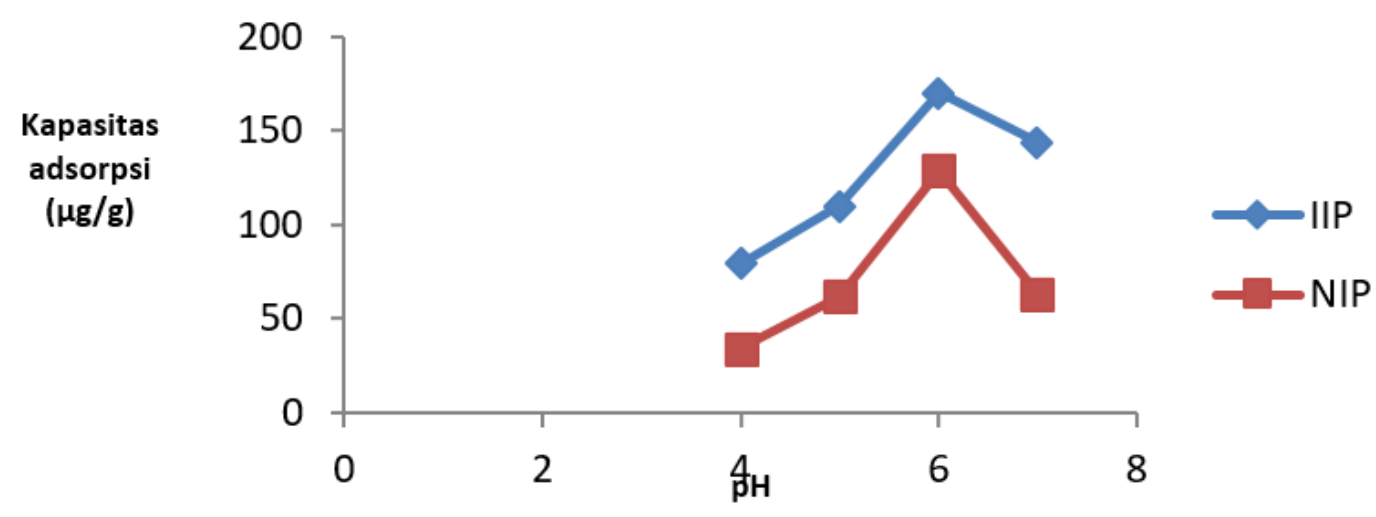

Gambar 6 Kurva penentuan pH optimum

standar $\mathrm{Cu}$ (II) 1 ppm pada $\mathrm{pH}$ optimum, yaitu pH 6. Waktu kontak dibuat bervariasi antara 20 -120 menit.

Semakin lama waktu kontak maka kapasitas adsorpsi akan semakin meningkat (Gambar 7). Hal itu disebabkan karena seiring meningkatnya waktu kontak, maka akan lebih banyak $\mathrm{Cu}$ (II) yang teradsorpsi hingga mencapai keadaan setimbang. Namun setelah 80 menit kapasitas retensi $\mathrm{Cu}$ (II) menurun karena setelah mencapai keadaan setimbang, maka laju desorpsi akan berlangsung lebih cepat maka kemampuan polimer untuk mengadsorpsi $\mathrm{Cu}$ (II) tidak efisien lagi sehingga kapasitas adsorpsinya menurun.

Kapasitas adsorpsi $\mathrm{Cu}$ (II) baik IIPs dan NIP ditentukan dalam metode Batch pada rentang konsentrasi 2,5-12,5 ppm. Semakin besar konsentrasi larutan $\mathrm{Cu}(\mathrm{II})$ yang digunakan semakin besar juga jumlah ion yang diperoleh dapat dilihat pada Gambar 8.
Kapasitas retensi $\mathrm{Cu}(\mathrm{II})$ meningkat dengan meningkatnya konsentrasi $\mathrm{Cu}^{2+}$ yang dikontakan. Dari konsentrasi 2,5 ppm sampai $10 \mathrm{ppm}$ terjadi peningkatan konsentrasi yang tinggi, tetapi ketika konsentrasinya meningkat mennjadi 12,5 ppm terjadi sedikit peningkatan dalam NIP sementara di dalam IIPs tidak terjadi peningkatan konsentrasi (konstan) karena mencapai kesetimbangan dan drajat penutupan telah sempurna, sehingga adsorpsi desorpsi memiliki laju yang sama dan mencapai konstan. Kapasitas adsorpsi optimum untuk IIPs $408 \mu \mathrm{g}$ $\mathrm{Cu}^{2+/}$ gram dan untuk NIP $192 \mu \mathrm{g} \mathrm{Cu}^{2+/}$ gram. Kapasitas adsorpsi lebih besar karena setelah ion $\mathrm{Cu}(\mathrm{II})$ di lepaskan dari IIPs, terbentuk rongga dan juga cetakan ion yang ukuran dan koordinasi geometrinya sesuai untuk ion $\mathrm{Cu}(\mathrm{II})$. Sedangkan dalam NIP, gugus-gugus fungsi dalam polimernya memiliki distribusi yang acak sehingga tidak menghasilkan afinitas pengikatan yang spesifik.

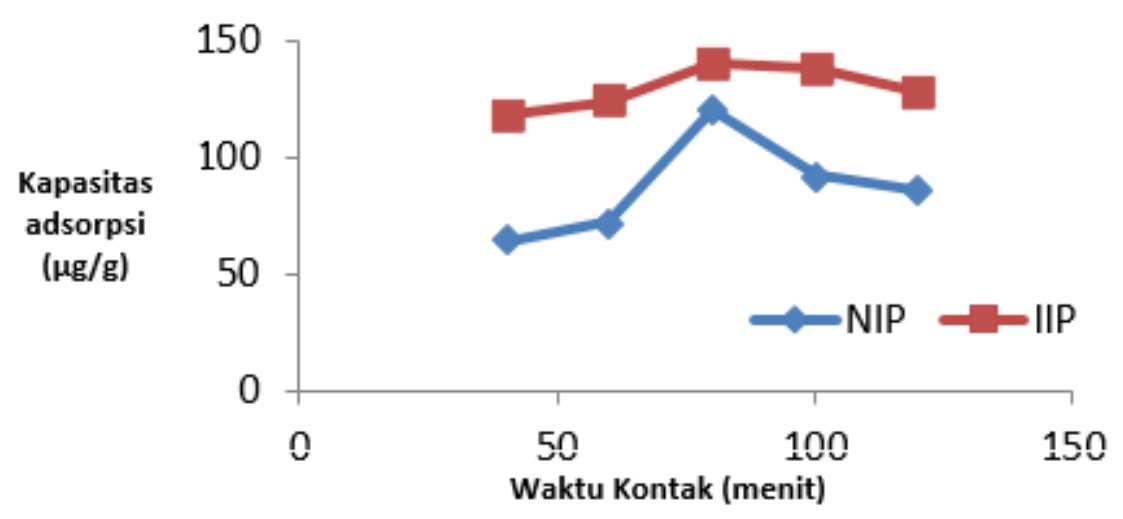

Gambar 7 Kurva penetuan waktu kontak optimum untuk IIPs dan NIP 


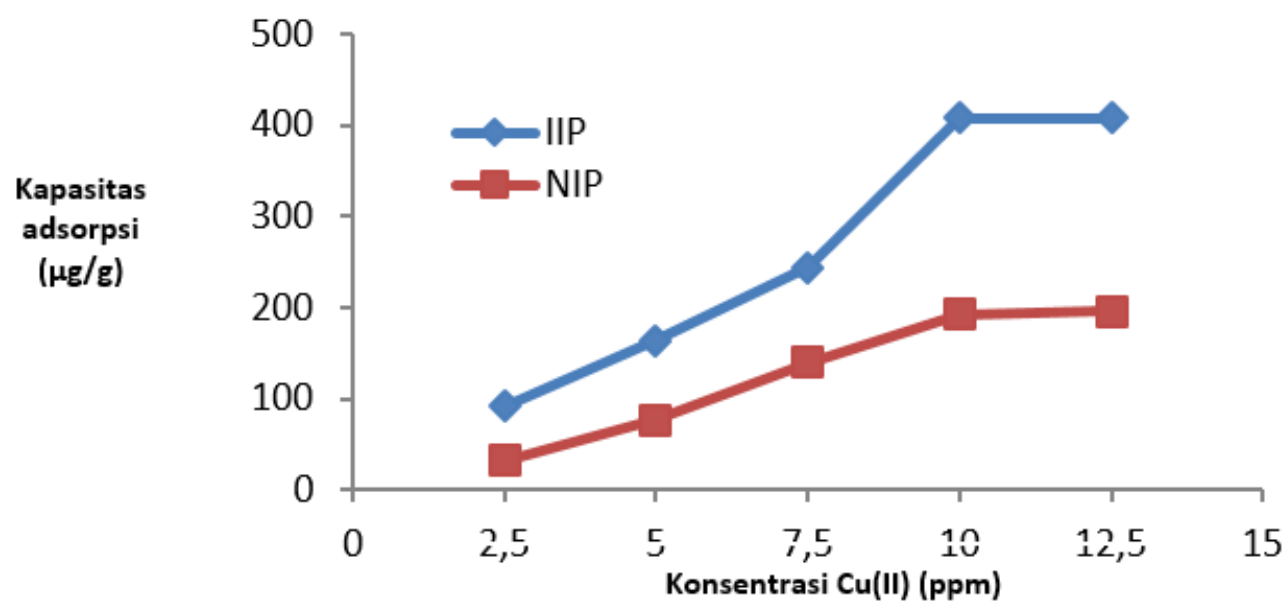

Gambar 8 Kurva kapasitas adsorpsi konsentrasi Cu(II) 2,5-12,5

Jumlah ion $\mathrm{Cu}(\mathrm{II})$ yang diadsorpsi persatuan masa IIPs dan NIP meningkat seiring dengan meningkatnya konsentrasi awal $\mathrm{Cu}$ (II), semakin banyak ion $\mathrm{Cu}(\mathrm{II})$, maka konsentrasinya pun akan bertambah maka otomatis kapasitas adsorpsi juga akan semakin meningkat. Ion $\mathrm{Cu}$ (II) diadsorpsi menggunakan IIPs dan NIP dan didesorpsi menggunakan larutan EDTA 0,05M.

Ion $\mathrm{Cu}$ (II) yang di serap oleh IIP dan NIP di tempatkan dalam media desorpsi dan diaduk pada temperatur ringan dengan jangka waktu yang berbeda. Desorpsi maksimum diteliti selama 1 jam untuk masing-masing perlakuan, disisi lain untuk perolehan kembali prosedur adsorpsi-desorpsi diulangi kembali dengan prosedur yang sama. Adsorpsi-desorpsi ini dilakukan dengan tujuan untuk mengetahui apakah IIP dapat digunakan berkali-kali dalam sampel atau tidak.

Persen perolehan kembali dalam penelitian ini sebesar 97,09\% untuk IIPs dan $53,11 \%$ untuk NIP. Nilai persen perolehan kembali yang baik berkisaran $100 \pm 5 \%$. Persen perolehan kembali IIPs adalah baik karena melebihi 95\%, tetapi NIP perolehan kembalinya sangat kurang baik karena nilai persentasenya jauh di bawah 95\%. Artinya IIP dapat diaplikasikan pada sampel dan dapat digunakan berkali-kali dengan persen perolehan kembali yang cukup besar.

\section{Kesimpulan}

$\mathrm{Cu}(\mathrm{II})$-imprinted polymers $(\mathrm{Cu}-\mathrm{IP})$ berhasil disintesis melalui polimerisasi asam salisilat dengan formaldehid sebagai pengikat silang, dengan adanya kompleks logam $\mathrm{Cu}$ (II) dan ligan 4-(2-pyridylazo)resorcinol dengan perbandingan $\mathrm{Cu}: P A R$ 1:1. Hasil karakterisasi dengan FTIR menunjukkan hasil sintesis memiliki gugus-gugus yang sesuai dengan gugus yang terdapat dalam IIP secara teori. Kondisi optimum retensi $\mathrm{Cu}$ (II) oleh $\mathrm{Cu}$-IP yaitu pada pH 6 dan waktu kontak 80 menit. Kapasitas adsorpsi $\mathrm{Cu}$-IP pada kondisi optimum adalah 10 ppm. Hasil adsorpsidesorpsi $\mathrm{Cu}-\mathrm{IP}$ pada $\mathrm{Cu}(\mathrm{II})$ menunjukkan persen perolehan kembali rata-rata $97,09 \%$ untuk IIPs dan 53,11\% untuk NIP.

\section{Referensi}

[1] Saepudin Suwarsa, dkk, (2008) pengembangan metode Prakonsentrasi dengan teknik Injeksi alir untuk analisis $\mathrm{Cu}$ dan $\mathrm{Pb}$ dalam aliran sungai waduk saguling. Jurnal penelitian universitas mulawarman, samarinda.

[2] Kawamura, S. 1991. Integrated Design of Water Treatment Facilities. New York: John Willey an Sons, Inc.

[3] Lee, J.D., 1994, Concise Inorganic Chemistry, Fourth edition, Chapman and Hall,London

[4] Jadid, A.P et,al. (2008), Preconcentration of cooper with solid phase extraction and its determination by flame Atomin Absorption 
Spestrometry, E-journal of chemistry, 5, 878883

[5] Ghaedi, Mehrorang. et,al. (2009) Determination of $\mathrm{Cu}, \mathrm{Fe}, \mathrm{Pb}$, and $\mathrm{Zn}$ by flame -AAS after preconcentration using sodium Deodecyl sulfate Coated alumina modified with complexing agent, Journal Of the Chinese chemical Society, 2009, 56. 150-15

[6] Lastri Herlina (2012), Ion imprinted polymers (IIPs) untuk ekstraksi fasa padat dan prakonsentrasi ion timbal(II), Tugas Akhir program SI, Universitas Islam Negeri Sunan Gunung Djati Bandung.

[7] D.K Singh, Shraddha Mishra (2009), Shyntesis of a new acu(II)-ion imprinted polymers for solid phase extraction and preconcentratiom of Fe(II), chromatographia, 70, 153-1545
[8] Modise Rammika (2010) an ion imprinted polymers for the determination of $\mathrm{Ni}$ (II) ions from mine tailing sample a thasis. Rhodes University.

[9] Paul preuss (1997) imprinted polymers woold selectively trap metal ions. Sience articles arcive Berkeley lab. Tersedia online: http://www.Lbl.gov/sciencearticles/Arcive/Im printedpolymers.html.

[10] Rao Tp. Kala R and Daniel S (2006) Metal ionimprinted polymers-novel materialis for selective re-cognition of inorganic. Anal chim. Acla 578.105.116

[11] Tuzen,Mustafa, et al. 2008. Determination of trace heavy metals in some textile products produced in turkey. Ethiopia. Chemical Society. 379-384 